\title{
Connected but not Engaged: A Tale of Two Governorship Candidates' Social Media Mobilization in a Gubernatorial Contest in Oyo State, Southwest Nigeria
}

\author{
Adebiyi Rasheed Ademola \\ Department of Mass Communication, Fountain University, Osogbo, Nigeria - rasheed.adebiyi@gmail.com
}

\begin{abstract}
Ajetunmobi Umar Olansile
Infoprations Limited, Lagos, Nigeria- ajetunmobiumarolansile@gmail.com
\end{abstract}

\section{Olawale Jelilat Opeyemi}

BBC Yoruba, Lagos, Nigeria - opeyemireal02@gmail.com

\begin{abstract}
The study analyses the engagement of potential voters with two major candidates for governor in the 2019 gubernatorial election in Oyo State, South-West Nigeria. The study explored the interaction, pattern of engagement as well as the extent to which their followers focused on issues of their campaigns on Facebook, Twitter and LinkedIn. To achieve these aims, the researchers put forward content-analysis of 3,193 comments of the followers of the two candidates on the three platforms from December 2018 to February 2019, using purposive and constructed week sampling techniques. Results showed that the two candidates were able to engage followers on

the selected online social media platforms. However, one had a more robust engagement than his rival. It was also noted that a large percentage of their followers $(1,409$ in 3,193) did not key into the campaign issues as expected. Despite the level of engagement, a one-way communication pattern was noticed on the part of the two candidates. Their followers' questions and observations were ignored. It is therefore recommended that media strategists of politicians should always make their engagement with the citizens online two-way symmetrical. Social media platforms should equally not be downplayed in political campaigns by Nigerian politicians.
\end{abstract}

Keywords: Social media, Citizen engagement, LinkedIn,

Facebook, Twitter, Adelabu, Makinde. 


\title{
Ligados, mas não comprometidos: Um Conto de Mobilização dos Meios de Comunicação Social de Dois Candidatos a Governador numa Disputa Governamental no Estado de Oyo, Sudoeste da Nigéria
}

\begin{abstract}
Sumário
O estudo analisa o envolvimento de potenciais eleitores com dois grandes candidatos a governador nas eleições governamentais de 2019 no Estado de Oyo, no sudoeste da Nigéria. $\mathrm{O}$ estudo explorou a interação, o padrão de envolvimento, assim como a medida em que os seus seguidores se focaram nas questões das suas campanhas no Facebook, Twitter e Linkedin. Para alcançar estes objetivos, os investigadores apresentaram uma análise de conteúdo de 3.193 comentários dos seguidores dos dois candidatos nas três plataformas entre Dezembro de 2018 e Fevereiro de 2019, utilizando técnicas de amostragem com objetivos específicos e construídas durante a semana. Os resultados mostraram que os dois candidatos conseguiram atrair seguidores para as plataformas de redes sociais em linha

selecionadas. No entanto, um tinha um compromisso mais robusto do que o seu rival. Foi igualmente observado que uma grande percentagem dos seus seguidores (1.409 em 3.193) não se envolveu nas questões da campanha, como previsto. Apesar do nível de envolvimento, foi observado um padrão de comunicação unidirecional por parte dos dois candidatos. As perguntas e observações dos seus seguidores foram ignoradas. Por conseguinte, recomenda-se que os estrategas dos meios de comunicação social dos políticos façam sempre com que o seu envolvimento com os cidadãos on-line seja simétrico nos dois sentidos. As plataformas dos meios de comunicação social também não devem ser menosprezadas nas campanhas políticas dos políticos nigerianos.
\end{abstract}

Palavras-chave: Comunicação social, Envolvimento do cidadão, LinkedIn, Facebook, Twitter, Adelabu, Makinde.

\section{INTRODUCTION}

In recent years, social media are said to have recorded a significant impact on public discourse and communication in society. In particular, social media are increasingly being used in political contexts. More recently, micro-blogging services (e.g., 
Twitter) and social network sites (e.g., Facebook) are believed to have the potential for increasing political participation (Theocharis \& Lowe, 2016; Chu, Tseng, \& Chen, 2019). While Twitter is an ideal platform for users to spread not only information in general, but also to publicly share political opinions through their networks, political institutions (e.g., politicians, political parties, political foundations, etc.) have also begun to use Facebook pages or groups for the purpose of entering into direct dialogue with citizens and encouraging more political discussions (Stieglitz \& DangXuan, 2012). This trend raises many questions such as the nature of social media for political engagement, the place of social media interaction in offline political participation, among others.

In fact, scholars believe that the rise of new technologies has brought about a meaningful shift in the landscape of communication, and continues to transform the interactive patterns of citizens. As such, Bae (2014) argues that the use of digital technologies allows individuals to easily connect with others, and easily navigate communicative boundaries to discuss matters that interest them. No wonder social media has been defined in diverse ways. For instance, Kietsmann, Hermkens, McCarthy and Silvestre (2011, p.241) posit that "social media employ mobile and web-based technologies to create highly interactive platforms via which individuals and communities share, create, discuss and modify user-generated content." Spates, Kaufmann, Lin, Lachlan and Spence (2020) describe user-generated content as any online content in the form of opinions, comments, community reports, photos or response to other online users' comments. On the other hand, Theocharis and Lowe (2015) see social media as uniform platforms which can either mobilise or reinforce political participation. Furthermore, among political communication experts, online or social media engagement is also known as digital engagement. According to Bonneman (2013), cited by the International Association for Public Participation in its 2017 Working Paper, digital engagement is the "use of information and communications technologies to support, enhance or extend public participation and civic engagement processes."

In 2008, the U.S. Presidential elections marked a historic episode in the political realm, when for the first time, social networking sites allowed users to share their support for a specific candidate or interact with others on political issues (Muntean 2015). The trend continued in 2016 when Hillary Clinton of The Democrats and Donald Trump of The Republicans ran for the presidency of the United States of America. Also, in Asia, Asia News Monitor (2010) states that the 2012 South Ko- 
rean presidential election offers an excellent opportunity to explore the dynamics of cross-cutting exposure and political expression on social media. Reports, during the Egyptian political upheavals in 2011, show that citizens in Egypt communicated primarily through social media to learn about protests, which increased the odds of their participation (Tufekci \& Wilson, 2012).

In Nigeria for instance, the use of social media by political office seekers for political mobilisation first surfaced in 2011 Nigerian national elections. This claim did not undermine its deployment to monitor the 2007 electoral process which stimulated public discussion and collective action (Ifukor, 2010). Since then, Nigerians have explored the power of social media platforms like Facebook and Twitter to interact and engage in political campaigns, marketing, sensitisation, mobilisation and even propaganda in subsequent national elections (Taiwo, 2015; Aduloju, 2016). For electioneering purposes, social media platforms were employed in the 2015 elections for constructive and destructive arguments with politicians (Aduloju, 2016) to facilitate mass political participation; influence political self-expression and seek information on the elections (Jibril \& Yakubu, 2017).

Interestingly, data suggest that as the use of social media percolates from national elections down to elections at other levels of the federating units in the country, the purpose of use begins to assume a frightening dimension. The social media platforms became instruments in the hands of politicians to abuse, malign and spread damaging rumours about their opposing candidates. For instance, the November 2017 Anambra State, South Eastern gubernatorial election was largely criticized for what Dunu (2018) described as "internet brigandage, fake news, social media nuisance and character vilification" which characterized the use of social media (especially Facebook and WhatsApp) platforms for campaigns for the elections. On a similar note, the September, 2018 Osun State, South-Western governorship election also reported politicians inducing registered voters with money using social media. These social trends indicate that social media is gradually becoming a significant tool for political interaction, participation and marketing with a high tendency to be misused by Nigerians and Nigerian politicians (Ugwuanyi, Olijo, \& Celestine, 2019; Shadrach \& Apuke, 2020). Consequently, this gives impetus to this study to examine the politician's online engagement of candidates in Nigerian state-level elections. Thus, this study sought to do this by interrogating the politician-citizen online engagement of two major aspirants for the 2019 governorship election in Oyo State, South-Western Nigeria. 
Relying on the propositions of the Theory of Information Society, this study sought to know the direction of engagement and extent of interaction the two candidates had with their online followers. An information society, as postulated by Mhlomi and Osunkunle (2017), is characterised by interactive communication platforms, which allow the potential voter and the political candidate to disseminate information and provide feedback to one another. Such society considers the creation, distribution, use, integration and manipulation of information as a significant economic, political and cultural activity. That kind of society, enabled by the internet, provides opportunities for more people to represent their views and to participate online in communicative dialogues. However, one of the uncertainties over this access to user-generated content is that these new voices might not be heard and responded to by the traditionally powerful actors in society and their voices might not influence and control social actions. The study probed the kind of communicative dialogue that was apparent from the two governorship candidates' connection with followers and potential voters online.

\section{STATEMENT OF PROBLEM}

The available body of literature on political communication indicates that many researchers have conducted studies on the influence of social media on citizens' political participation, digital engagement and political participation as well as the use of social media for political marketing and electronic participation (Aichholzer \& Allhutter, 2009; An, Cha, Gummadi, \& Crowcroft, 2011; Vonderschmitt, 2012; Ekman \& Amna, 2012; Lamprianou, 2013; Hemphill \& Roback, 2014; Ayankoya, Cullen \& Calitz, 2015). This scholarly attention has established the importance of social media in political mobilization across the world.

The trend to use social media became noticeable in Nigeria shortly before the 2011 general elections when the then-president Goodluck Jonathan launched $M y$ Facebook Friends and I in Lagos, the commercial capital of the country (Okoro \& Nwafor, 2013). Since then, the trend has become more glaring in both national and state elections in the country. Elections that were conducted after the 2011 experience witnessed a huge deployment of social media for political campaigns (Miller, 2016; Chinedu-Okeke and Obi, 2016). Specifically, patterns of online political communication studies from Nigeria show empirical findings on youth networks on Facebook 
and Twitter during the 2015 general elections in Nigeria (Aduloju, 2016), the use of social media for political marketing (Ayankoya, Calitz \& Cullen, 2015), reactions of users to the 2015 presidential election on Facebook (Jibril \& Yakubu, 2017), the role of social media in the 2015 presidential election in Nigeria (Olowojolu, 2016), etc.

There has equally been some attention paid to individual online behaviour of selected Nigerian politicians and their online engagement. For instance, Aduloju (2016) posits that Facebook and Twitter played important roles before the 2015 presidential election in Nigeria, especially in the areas of electioneering, political campaigns, mobilisation and enlightenment of the electorate; Olowojolu (2016) asserts that Ex-President Jonathan actively engaged millions of Nigerian youths through the active use of social media like Facebook, while Barlett, Krasodomski-Jones, Daniel, Fisher and Jesperson (2015) reveal that Muhammadu Buhari's digital drive (social media) was intended to appeal to younger people. This pattern is an indication of a minimal scholarly attention received by candidates using social media to engage voters online. This is the void this study sought to fill by exploring further the engagement of citizens on three social media platforms (Facebook, Twitter and LinkedIn) by two major governorship aspirants in the 2019 gubernatorial election in Oyo State, South-West Nigeria with the aim of determining the direction, focus and level of engagement in the citizen-politician interaction.

\section{LITERATURE REVIEW}

\section{Social Media as a Tool for Mobilization and Political Participation}

In recent years, social media are said to have an impact on public discourse and communication in society. In particular, social media are increasingly used in political context. More recently, microblogging services (e.g., Twitter) and social network sites (e.g., Facebook) are believed to have the potential for increasing political participation. While Twitter is an ideal platform for users to spread not only information in general but also political opinions publicly through their networks, political institutions (e.g., politicians, political parties, political foundations, etc.) have also begun to use Facebook pages or groups for the purpose of entering into direct dialogues with citizens and encouraging more political discussions (Stieglitz \& Dang-Xuan, 2013, p.1).

Political behaviourists keep arguing on the implications of social media use and offline political participation. Some have defended that the use of social media does 
not have positive effects on offline political participation of people, while some have argued that it does have great effects on offline political participation. For instance, Theocharis and Lowe (2015) assert that the use of Facebook (a social medium) has a clear negative effect on civil and political participation, while Zhang, Johnson, Seltzer, and Bichard (2009) and Enjolras, Steen-Johnsen and Wollebaek (2013) reported positive effects of Facebook on political participation. Sharing the positive impact of social media, Vraga, Anderson, Kotcher and Maibach (2015) argue that the media promote politicians and their activities. Even, the multimedia nature of social media makes information (be it political or otherwise) easily available and accessible for people (Calderaro, 2018). In fact, the social media really set public agenda in the political campaigns and other electioneering activities in Israel (Haleva-Amir, 2011; David, Zhitomirsky-Geffet, Koppel, \& Uzan, 2016; Satterfield, 2016) and the United States of America (Carlisle \& Patton, 2013; Quinlan, Gummer, Roßmann, \& Wolf, 2017).

\section{Citizen Engagement (Online) as a Form of Political Communication}

Many political communication experts and new media strategists have defined and discussed the concept of citizen engagement, citizen involvement or citizen participation in different ways. One of the emerging views is that engaging citizens for political discussions on social media platforms is a way of developing and implementing innovation in the political space. Davies and Simon (2013) for instance describe citizen engagement with three attributes. One, people participate in engagement activities voluntarily, though incentive can be given for participation. Two, engagement requires some form of action from citizens as participants are not passive. Last, engagement activities are usually directed towards a common purpose or goal- social mission. According to Meskell (2009, p.1-2), citizen engagement "builds communities around the issues that people find important, lets the community members interact with one other, and eliminates barriers associated with physical distance and travel costs and other impediments facing citizens who want to have their voices heard".

The means by which political actors communicate have changed fundamentally. Nowadays, a lot of this communication is done via the Internet and social media (Vliegenthart \& Mena Montes, 2014 citing Smith \& Rainie, 2008). Research shows that aside politicians and media performing the role of agenda control, the citizens also selectively attend to political issues that interest and are important to them at the moment of engagement. With strategic communication, Mead (2018) establishes that citizen engagement offers both the citizens and development agents a better 
understanding of problems and needs, opinions and priorities as well as promotes community representation in decision making. When citizens are involved in decision making through effective engagement, there will be open and more transparent leadership that builds citizen trust in government. However, the researcher argues that online engagement might result in disconnection between citizens and politicians when citizens' attention can no longer be sustained. Disconnection is also possible because engagement involves a great deal of planning and foresight.

\section{Online Citizen Engagement among Nigerian Politicians}

In Nigeria, politicians are gradually annexing the potential of social media unlike in developed nations where a radical adoption of social media for political campaigns and engagements is becoming a trend. An instance is the report of the International Centre for Investigative Reporting (ICIR 2018) about the campaign behaviours of five leading candidates on Twitter before the 2018 gubernatorial election in Osun State. The analysis scored all the candidates very low in engaging citizens/potential voters on Twitter.

However, Dunu (2018, p.8) argues:

social media may involve more people to participate. Getting information, stating opinions and communicating with a large number thus becomes possible and easy. This is an important reason why politicians and political parties and other political actors find it to be important and that is why we see that in political campaigns social media have become effective tools for mobilization. The Anambra 2017 and the 2015 general elections in the country are a case in point.

She adds that during the 2011 general elections, many politicians, the presidential aspirants, gubernatorial aspirants and other individuals mostly and widely used Facebook and Twitter to connect with voters and constituents, for political campaign and sensitization.

Social media outlets are essential to politicians and political parties, enabling them to gain support, encourage participation and have an open and continuous dialogue (Michael, 2017, p.17). 
Okolo, Ugonna, Nebo and Obikeze (2017) maintain that Nigerian politicians have begun the use of Facebook and Twitter because the media platforms are believed to have the potential of positively influencing political participation. They further submit that the use of social media "secures victory and encourages interaction between political parties/candidates and voters, and most times to portray positive image of the political candidates".

Also in another perspective, Michael (2015) finds out that the social media were more than communication platforms in the 2015 general elections in Nigeria; the media become strong forces of political mobilisation and means through which netizens took part in the electoral process with the hope that democracy and mass participation in politics could be attained with these media.

Moreover, Okoro and Santas (2017) investigated the utilisation of social media for political communication in the 2011 Nigerian presidential election and found out that social media influenced the respondents' choice of presidential candidate, affirming that the two main presidential candidates were more popular because they used social media in their political campaign. Another revealing finding was the respondents' affirmation that their voting pattern during the elections was greatly influenced by social media usage (political communication on social media) of the two candidates. On the contrary, Akinlade's (2015) investigation reveals that though the Nigerian youths resident in the southeastern region is very active on social media, social media does not have an influence on their voting preferences.

When Barlett, Krasodomski-Jones, Daniel, Fisher and Jesperson (2018) examined the Nigerian 2015 general elections, they reported that Twitter was mostly used by politicians for political campaigns, and it mobilised and influenced people to vote for a particular candidate. A similar finding was reported by Apuke (2017). According to them, Facebook was used in the 2015 senatorial electioneering campaigns in southern Taraba, and that action influenced electorate to vote a particular candidate. The study of six researchers, Bright, Hale, Ganesh, Bulovsky, Margetts and Howard (2017) on the political Twitter activity in the 2015 and 2017 elections in the United Kingdom also reveals that Twitter-based campaigning help win votes. Interestingly, they argue that when politicians have more followers on Twitter, the possibility of recording greater direct mobilisation of the followers is high.

Similarly, Apuke and Tunca (2018) submit that in 2011 and 2015 general elections in Nigeria, politicians employed social media to engage potential electorate due to its participatory nature and potential for political campaigns, electioneering mobiliza- 
tion as well as ideological manifestation/trumpeting. However, during these years, the researchers assert that politicians used social media to de-market or destroy the image of their opposition party's standard-bearer alongside his political party.

Going by the current information age, every politician who is ready to involve and engage online electorate must show presence and activeness on important social media platforms. In an opinion article published by the Nigerian Tribune, Dike (2018) categorically emphasizes:

That many Nigerians have embraced and are deeply involved in the world of social media may be stating the obvious as it would be disastrous for politicians not to fully embrace this important information platform. Election battles are going to be on social media and less at the big rally fronts. Politicians will have to familiarise themselves with social media, make their presence felt and stay engaged positively with the electorate.

Dike states further that "Twitter and Facebook have become instrumental in organising campaigns as campaigns are going viral. They allow like-minded voters and activists to easily share news and information such as campaign events with each other. That's what the "Share" function on Facebook and "retweet" feature of Twitter is for."

In the submission of Orjimi (2018), the two main presidential candidates in the 2019 election in Nigeria, President Muhammadu Buhari and Alhaji Atiku Abubakar, heavily used Facebook and Twitter to communicate and emphasize their campaign promises to the potential electorate. In his words, "ahead of 2019 however, it would seem like the two leading candidates, APC's Muhammadu Buhari and PDP's Atiku Abubakar, have been engaging in lots of social media battles for dominance. Although some of the engagements by their teams and supporters have been acidic, puerile and shallow, the candidates and their running mates (APC's Yemi Osinbajo and PDP's Peter Obi) have repeatedly used social media increasingly to either pass crucial pieces of information or address trending issues for or against themselves."

However, Ezeibe (2015) establishes that social media use by aspirants during the 2015 general elections was not centred on issue-based campaigns. Instead, social media users focused on issues that are insignificant to democratic governance.

Recent observations have pointed out that the contemporary and technologically savvy politicians now complement their online campaigns with infographics. Ching (2018) asserts that aside from that infographics are used by major companies to illus- 
trate statistics, research results, and business presentations, they are now increasingly prevalent as a political campaign and promotional tool. According to the researcher, infographics which are also used to lure and retain visitors (people) with useful information in an attractive format perform four significant functions: they increase traffic over time (the users achieve some degree of stardom on social media networks like Facebook, Twitter or LinkedIn), enable long-term investment in the success of campaigns, improve overall authority and rankings as well as encourage engagement and people's interest.

\section{RESEARCH OBJECTIVES}

1. To evaluate the focus of the citizens-politician engagement of the two major governorship candidates in the 2019 gubernatorial election in Oyo State on Facebook, Twitter and LinkedIn.

2. To explore the patterns of mobilisation adopted by the two aspirants (Was the pattern targeted at campaign issues, attack on the personalities of the candidates or both? How did the candidates respond to the followers' questions? To what extent did the candidates complement their engagement with multimedia like corresponding pictures, videos and infographics?)

3. To examine the extent to which followers of the two candidates engaged and keyed into issues of the campaign.

\section{RESEARCH QUESTIONS}

The following research questions were raised for the study:

i. To what extent did Engineer Seyi Makinde (of the PDP) and Mr Bayo Adelabu (of the APC) engage their followers on Facebook, Twitter and LinkedIn?

ii. What are the patterns of Engineer Seyi Makinde and Mr Bayo Adelabu's citizen communication/mobilisation on Facebook, Twitter and LinkedIn?

iii. To what extent did the followers of the two candidates key into issues of the campaign? 


\section{METHODOLOGY}

The researchers adopted content analysis research design, and the study population comprised the comments of all the followers of Engineer Seyi Makinde and Mr Bayo Adelabu on their campaign posts on Facebook, Twitter and LinkedIn. The study period was from December 2018 to February, 2019. As of February, Engineer Seyi Makinde (@seyimakinde) had 12,800 followers on Twitter while Mr. Bayo Adelabu (@BayoAdelabu) had 6,623 on Twitter. On their Facebook pages, Engineer Seyi Makinde (Engineer Oluseyi Makinde) had 60,230 followers while Mr Bayo Adelabu (BayoAdelabu) had 37, 486 followers. Though Mr Bayo Adelabu operated no LinkedIn account, Engineer Seyi Makinde had 20, 519. The researchers adopted purposive and constructed week sampling techniques. Purposive sampling was used to select 3, 193 comments that resonated with the content categories the researcher worked with. The number of content categories for each of the candidates differed because the numbers of their campaign promises were not similar. On the other hand, constructive week sampling technique occurs whenever contents are stratified based on the days of the week. Since the scope of this study lasted three months - December 2018 to February 2019 -, the total number of weeks constructed for the content categories then rose to twelve. After coding and analysis, 877 comments were used as the sample size for Mr Bayo Adelabu's engagements on Facebook and Twitter. His LinkedIn engagement was not included in the study because he did not have a LinkedIn account. However, for Engineer Seyi Makinde of the PDP, 2,316 comments were selected as sample across his Facebook, Twitter and LinkedIn accounts. Altogether, 3,193 comments on the Facebook pages, Twitter and LinkedIn accounts of the two candidates became the sample size for the entire study. Also, every issue-based engagement of the two candidates starting from December 2018 to February 2019 was included in the sample. Putting the purpose of the study in mind, the researcher did not select any of the two candidates' posts that intimated their followers with their campaign trains within the nooks and crannies of Oyo State.

The researchers also adopted two different coding sheets for the two candidates because the content categories used for each candidate differed. For Engineer Seyi Makinde of the PDP, his campaign promises were adapted as the content categories for his social media engagement. A similar pattern was followed for Mr Bayo Adela- 
bu of the APC. Engineer Makinde's campaign promises included "Inclusive Government, Job Provision, Sustainable Use of Resources, Adequate Funding of Education, Improved Living Standard, Affordable Health Care, Infrastructure (roads, electricity and water) and Agriculture" while those of Mr Adelabu were to create "More Jobs, More Revenue, More Cottage Industries and More Money for Farmers (more food security and improved agriculture for people) as well as Improved security (through massive street lighting)." All these were categorised as "Focus of Engagement." The content categories for the second research question (for the two candidates), which was tagged "Pattern of Engagement", include "Issue-based engagement from the citizens, Personality-attack from the politician and Personality attack from citizens." Others were "Politician's response to questions and issues, use of multimedia aids during engagement and irrelevant comments from citizens." The units of analysis for the exploration comprised words, sentences and themes that resonated with the content categories.

\section{RESULTS AND DISCUSSION OF FINDINGS}

\section{The extent of the Candidates' Mobilization of Their Followers on Facebook, Twitter and LinkedIn}

The analysis in Figure 1 shows that Mr Bayo Adelabu engaged his potential voters to a large extent. He flooded his two main social media handles, Facebook and Twitter with campaign promises such as creation of more jobs, facilitation of more Internally Generated Revenue (IGR) and establishment of more small industries. Other promises included improved agriculture and food security as well as improved security through massive street lighting and CCTV monitoring. He discussed more of these issues on Facebook than Twitter. Mr Adelabu's readiness to create more jobs amounted to $75 \%$ on Facebook, but $25 \%$ of Twitter. His proposal to create more revenue through IGR indicated $60 \%$ and $40 \%$ on Facebook and Twitter respectively while his quest to establish more cottage industries showed $71.4 \%$ on Facebook, but $28.6 \%$ on Twitter. The analysis further shows that Mr Adelabu's plans for farmers through improved agricultural system and food security amounted to $46.2 \%$ and $53.8 \%$ on Twitter and Facebook respectively. His posts on improved security resulted in $38.5 \%$ on Twitter, but $61.5 \%$ on Facebook. 


\section{Figure 1}

Mr Bayo Adelabu's Focus of Mobilization on Facebook and Twitter

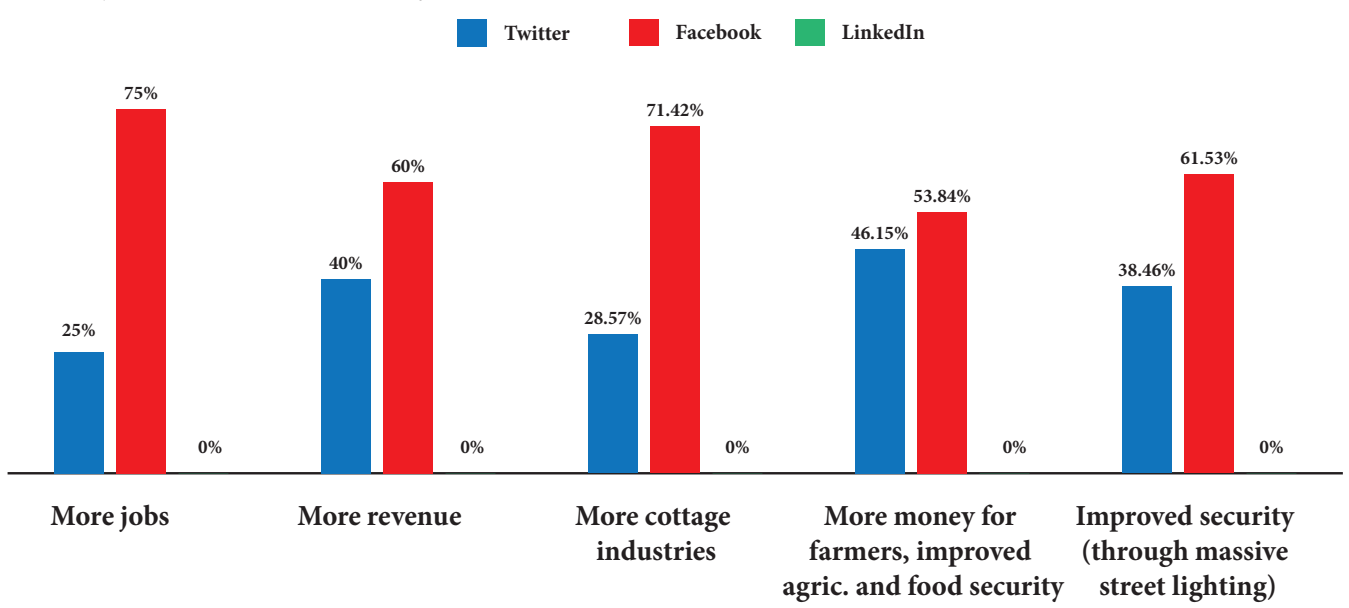

Source: Researchers' Analysis (2019)

In addition, the figure clearly shows that Mr Bayo Adelabu used more of Facebook than Twitter to engage potential voters, but he did not adopt LinkedIn throughout the three months. In his engagement on Facebook, creating more jobs recorded high mention while creating more cottage industries came second, followed by improved security. Facilitating more money for farmers through improved agricultural practice and food security came next to generating more revenue for Oyo State.

For example, he believed that if storage facilities are provided for farmers in Oyo State, if the old farm settlements are refurbished, if a commodity board is established to stabilize prices of farm produce and if livestock farming is maximally encouraged, the outcome would not only improve the well-being of farmers but also increase the state's IGR, create more employment for people and enhance food security and sustenance in Oyo State. He also assured the potential voters that his administration would invest in tourism and relaxation hubs, thereby improving the economic status of the state. On security, Mr Bayo Adelabu was convinced that having CCTV network in some hotspots in Ibadan, the state capital, will curtail crimes before such crimes are even committed, considering the fact that control rooms and security call numbers would be available all the time. 
Connected but not Engaged: A Tale of Two Governorship Candidates'

Social Media Mobilization in a Gubernatorial Contest in Oyo State, Southwest Nigeria

\section{Figure 2}

Engineer Seyi Makinde's Focus of Mobilizations on Facebook, Twitter and LinkedIn

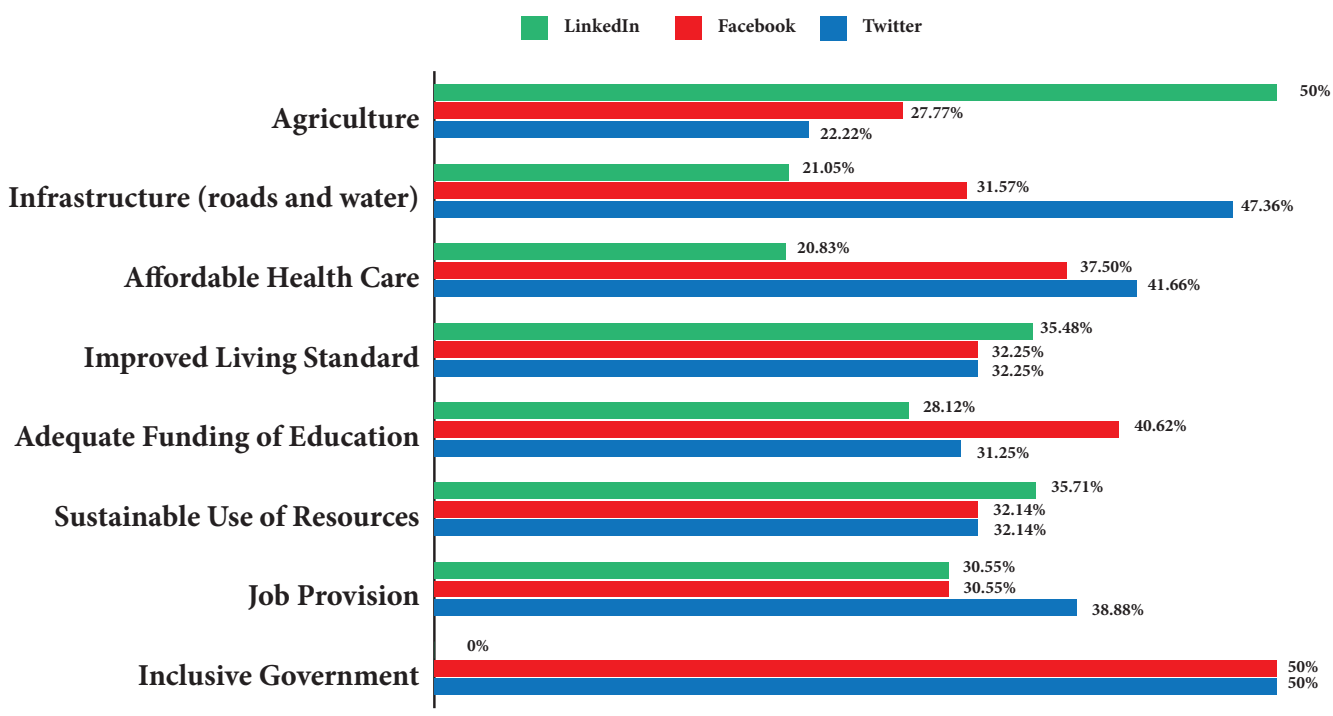

Source: Researchers' Analysis (2019)

Figure 2 shows an insight on how Engineer Seyi Makinde of the PDP directed his engagement to his followers on Twitter, Facebook and LinkedIn. From the analysis, Engineer Makinde engaged his followers more on job provision, adequate funding of education and improved living standard of people of Oyo State. Other areas he promised his administration would keenly look into should he is voted in as the governor include sustainable use of resources, affordable health care, infrastructure such as roads, electricity and water, agriculture as well as inclusive government.

For instance, he promised to create massive employment through agriculture and waste management. He believed that growing cash crops like cocoa, cotton, groundnut and oil palm as well as cultivating food crops like yam, cassava, millet, vegetables and sorghum in Oyo State would go a long way to improve the living standard of his people and ensure food security in the state. According to him, it would also reduce the rural-urban migration of the populace. To improve the living standard of his people, the aspirant also promised to eliminate multiple taxation, create direct and indirect investments and formulate business-friendly policies. On education 
across board, Engineer Makinde's interventions would be to commit 10\% of the yearly budget to funding education and to initiate the possibility of outright ownership of LAUTECH Ogbomoso so that Oyo State can be directly responsible for its management. According to him, his administration would also provide optimal learning environments such as well-furnished classrooms for all state primary and secondary schools and better working conditions for teaching and non-teaching staff of the schools. Engineer Makinde also promised the potential voters that his administration would upgrade the rural feeder roads in all the 33 LGAs, invest in housing, energy and water supply, empower youths, upgrade primary healthcare centres (PHCs) and implement a feasible health insurance scheme, among others.

From the foregoing, it could be deduced that he used social media platforms based on the caliber of people to be engaged on them. For instance, he used more of LinkedIn to discuss agriculture, but Facebook and Twitter to talk about inclusive government. Engineer Makinde as well used more of Twitter to discuss his plans and strategies on infrastructural development, affordable health care and provision of jobs. It could be inferred that Engineer Makinde's engagement is based on the nature of the social media and the demographics the platforms engaged most. In summary, Engineer Seyi Makinde of the PDP used the three social media for his direction of engagement to his online followers.

\section{Table 1}

Extent of Using Social Media by the Candidates and their Followers for Mobilization

\begin{tabular}{lcccc}
\hline Candidate and the Medium & Mean & T & Df & P-Value \\
\hline Adelabu on Twitter & 3.00 & .000 & 5 & 1.000 \\
Makinde on Twitter & $\mathbf{8 . 5 0}$ & $\mathbf{4 . 1 1 6}$ & 7 & $\mathbf{. 0 0 4}$ \\
Adelabu on Facebook & 4.83 & 1.534 & 5 & .186 \\
Makinde on Facebook & $\mathbf{8 . 1 3}$ & $\mathbf{4 . 0 6 8}$ & $\mathbf{7}$ & $\mathbf{. 0 0 5}$ \\
Adelabu on LinkedIn & .00 & .000 & 0 & .000 \\
Makinde on LinkedIn & $\mathbf{7 . 3 8}$ & $\mathbf{3 . 1 2 3}$ & $\mathbf{7}$ & $\mathbf{. 0 1 7}$ \\
\hline
\end{tabular}

Source: Researchers' Analysis (2019) 
It is worthy of note that the insights from the direction of engagement of the two politicians is a reflection of the fact that politicians, having understood the potency of social media, use them to connect their agenda/programmes with the people (Stieglitz \& DangXuan, 2013; Larsson, 2015; Udoka, 2015; Haleva-Amir, 2016; David, Zhitomirsky-Geffet, Koppel and Uzan, 2016; Steinfeld, 2016; Okeke, Chinonye \& Obi, 2016; Apuke \& Tunca, 2018 and Verjee, Kwaja, and Onubogu, 2018). In fact, there is evidence from the literature that politicians are now adopting social media for campaigns because the platforms are capable of mobilizing potential voters and encouraging political participation (Okolo, Ikechukwu, Gerald \& Chinedum, 2017; Dunu, 2018; Dike, 2018; Apuke \& Tunca, 2018; Orjimi, 2018). These connections were observed in the online engagement of Mr Bayo Adelabu and Engineer Seyi Makinde with netizens from December 2018 to February 2019, though Engineer Makinde had a better connection with his followers across the three social media platforms compared to his rival who made use of just only two- Facebook and Twitter. The social media usage of these politicians also affirmed that political candidates and potential voters disseminate information and provide feedback to one another. This is as captured in one of the propositions of the Information Society Theory. In this context, the politicians posted their campaign promises to the potential voters while the potential voters equally commented on the posts in the form of feedbacks.

\section{The pattern of the Candidates' Citizen Mobilization on Facebook, Twitter and LinkedIn}

On the pattern of mobilization employed by the two candidates for the citizens, analysis of the results revealed that there was some engagement between the candidates and their followers on Facebook, Twitter and LinkedIn. From the researchers' observations, the mobilization strategies witnessed some issue-based interaction, personality attack from citizens and politicians, politicians' use of multimedia and some irrelevant comments from the citizens to raised issues (See Figure 3).

During the period, there were comments on job provision, adequate funding of education, improved living standard, infrastructural development and improved health care. The posts of the two candidates attracted a number of comments from their followers. For instance, within the period of the study (December 2018 to February 2019), Mr Adelabu's followers on Facebook and Twitter engaged him with not less than four hundred and fifty-five comments while Engineer Makinde's followers on Facebook, Twitter and LinkedIn engaged him on his campaign promises with one thousand one hundred and thirty-four comments. It was observed that from $\mathrm{Mr}$ 
Adelabu's posts, there was no personality attack. But his rival, Engineer Makinde, had some posts that attacked the incumbent governor, his rival and the party platform. As expected, this erupted into an e-war of words by their followers as they engaged one another in name-calling.

\section{Figure 3}

The Patterns of Citizens' Mobilization by Mr Bayo Adelabu and Engineer Seyi Makinde on Facebook, LinkedIn and Twitter

\section{Pattern of Engagement}

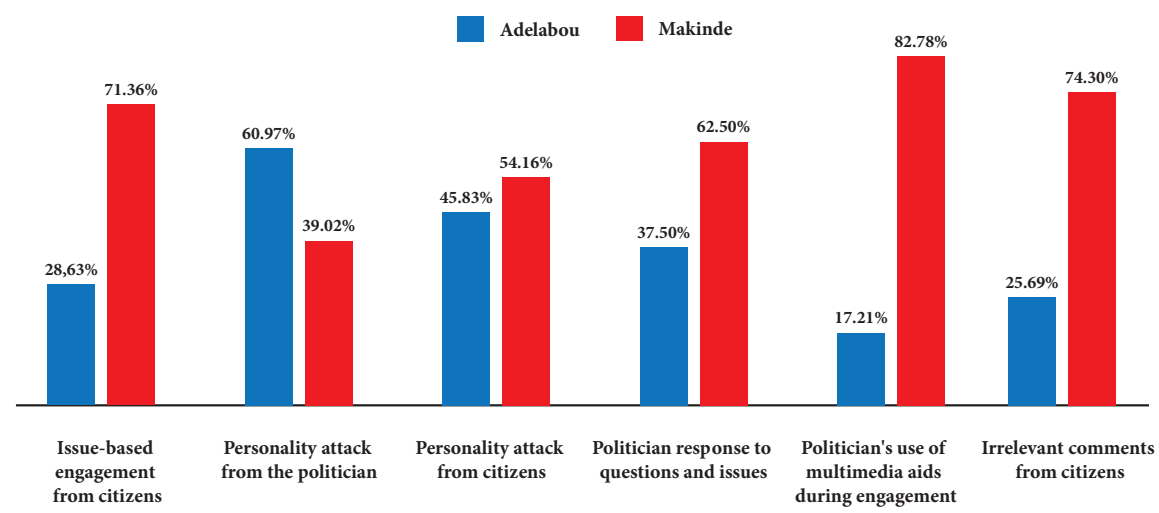

Source: Researchers' Analysis (2019)

Using social media to de-market rival candidates and parties has been found out to be one of the features of the use of social media, especially Twitter and Facebook. Specifically, Apuke and Tunca (2018) maintain that politicians used the social media to de-market or destroy the image of their opposition party's standard-bearer alongside his political party in the buildup to the 2011 and 2015 general elections in Nigeria.

Despite a noticeable level of social media engagement observed, the two politicians failed to adopt a two-way communication model. While their own posts attracted comments from the people generally, they did not respond to many questions raised by netizens. This may be an indication of their intention to only communicate and increase followership online without a corresponding will to entertain pertinent questions from the built followership. For the entire period of the study, the two candidates responded to eight questions in all. Engineer Makinde responded to five questions while Mr Adelabu responded to only three questions. Furthermore, the deployment of short videos, complementary pictures, infographics and other multimedia materials by both 
Connected but not Engaged: A Tale of Two Governorship Candidates'

Social Media Mobilization in a Gubernatorial Contest in Oyo State, Southwest Nigeria

politicians to complement their messages could be said to be an indicator of the politicians' perception of the online media as a one-way communication platform. They failed to make use of the interactive nature of the social media platforms.

\section{Figure 4}

Selected Campaign Materials of Mr. Adebayo Adelabu and Engr. Seyi Makinde

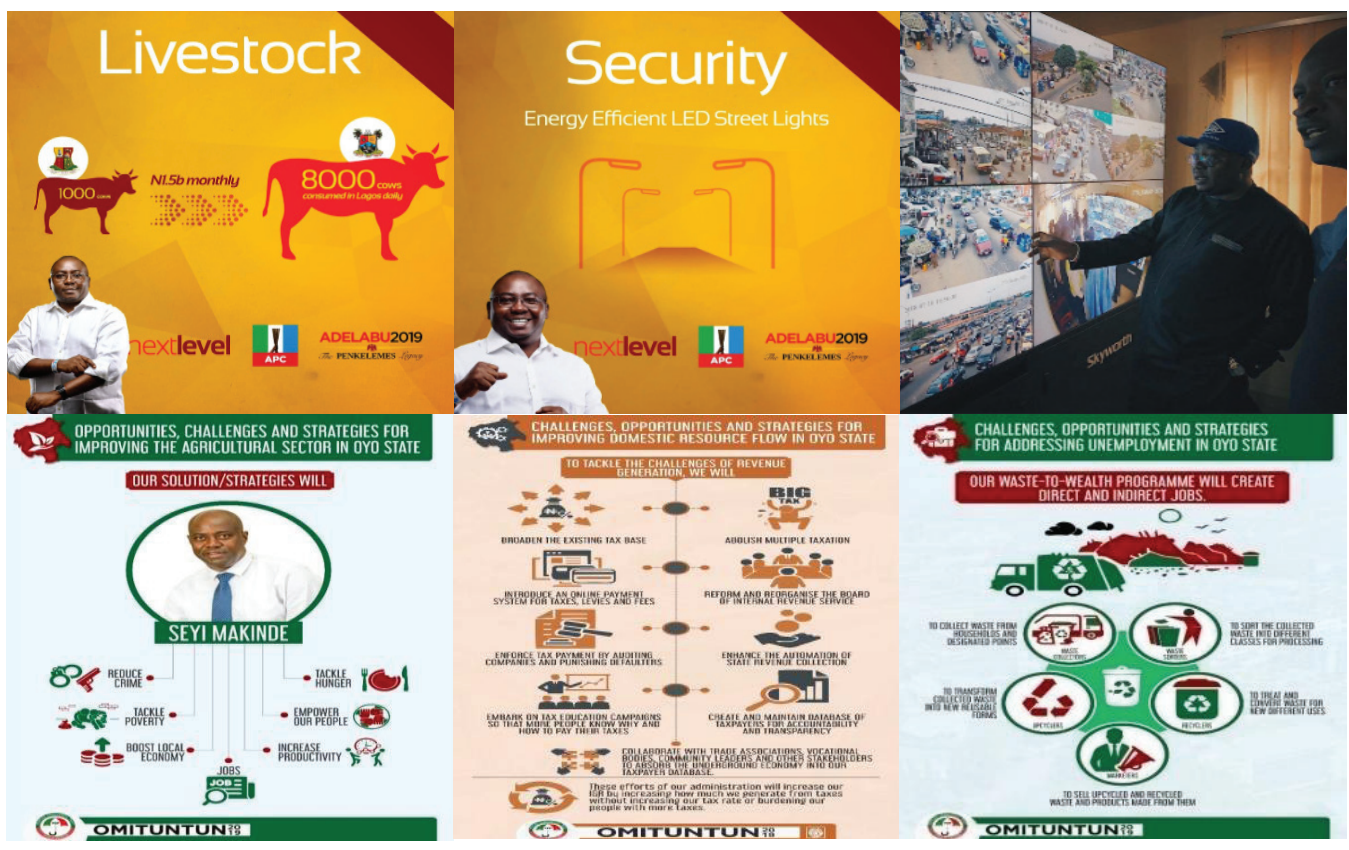

Source: Facebook and Twitter, 2019

\section{The Extent of the followers keying into issues of the campaign}

From the analysis, the extent of the followers keying into the campaign issues of the two candidates was not impressive. There is a myriad of comments that do not correlate with issues raised by the politicians. For example, irrelevant comments from the followers of the two candidates rose to one thousand four hundred and nine (44.1\%). The irrelevant comments mined from Mr Adelabu's posts across Facebook and Twitter amounted to $41.3 \%$ while those of Engineer Seyi Makinde on Facebook, Twitter and LinkedIn produced $45.2 \%$. Some of these irrelevant user-generated contents directly sought financial assistance from the candidates. These followers went to the extent of adding their account details to the body of their messages. Some other 
comments advertised the potency of some locally made drugs and how to get accommodation in certain areas in Lagos while some advertised the wonders of certain football betting companies. In fact, some followers had to advertise the businesses they do with a view to selling their services to the two candidates. In addition, some comments from the adherents of Islam and Christianity showed indifference; as such, they only prayed for the two candidates. All these comments were coded irrelevant because they did not literally and thematically correspond with the issues the politicians discussed. This indicates that only $58.7 \%$ and $54.8 \%$ of the social media followers of Mr Adelabu and Engiineer Makinde respectively keyed into the issues of their campaign. Thus, the rates of those whose comments contradicted the themes of the online engagement show a direct link with Ezeibe's (2015) findings that social media users did not focus on campaign issues in the 2015 general elections in Nigeria. The implication of this finding is that social media, especially Facebook, encourages self-expression and user-generated contents among the users (Jibril \& Yakubu, 2017; Michael, 2015), and as such, they are at liberty to express themselves without being cautioned by any primary gatekeeper. Interestingly, most of these irrelevant comments were aggregated from Facebook posts of the two candidates (888 comments, amounting to $63 \%$ of the 1409 comments).

Therefore, putting everything together, it can be concluded that Engineer Seyi Makinde of the People's Democratic Party (PDP) engaged his followers on Facebook, Twitter and LinkedIn more than Mr Bayo Adelabu of the All Progressives Congress (APC), perhaps testifying to the assertion of Dike (2018) that "it would be disastrous for politicians not to fully embrace this important information platform (social media) as "election battles are going to be on social media and less at the big rally fronts". Similarly, the study of Effing, Hillegersberg and Huibers (2011) reveals that Twitter contributed to how the people of Netherlands voted for a particular candidate in her 2010 national elections. According to them, the candidate who explored Twitter for political campaigns and mobilisation received more votes offline. Apuke and Apollos (2017), as well as Barlett, Krasodomski-Jones, Daniel, Fisher and Jesperson (2018) share the same argument when they revealed their findings on the impact of social media in the 2015 general elections in Nigeria. In fact, Kamp (2016) argues that social media provide opportunities for political leaders to strengthen their interaction with the citizens. However, the European Union's report (2018) argues that despite the increased adoption of social media, there has not been a generally agreed position on the influence social media has on Nigerian elections. Thus, the extensive 
use of Facebook, Twitter and LinkedIn by Engineer Seyi Makinde might be one of the salient factors that contributed to his victory in the gubernatorial election.

\section{CONCLUSION}

From our findings, it is established that social media engagement plays a significant role in the outcome of elections. Engineer Seyi Makinde had a more robust engagement with his followers on Facebook, Twitter and LinkedIn than Mr Bayo Adelabu did. He only used Twitter and Facebook for citizen engagement. Throughout the campaign periods, both of them engaged their followers on issue-based campaigns, but Engineer Makinde's engagement became more prominent in February when he dished out more problem-solution based messages.

Also, our findings indicate that Engineer Makinde engaged in personality attack. He attacked the personality of his rival, Mr Bayo Adelabu, and the then incumbent Governor Abiola Ajimobi who shared the same party platform with the APC candidate. Personality attack was missing from Mr Adelabu's posts within the study period. It was also observed that the social media platforms employed were used as more of a one-way communication channel. Responses on posts from the politicians were off the tangent sometimes being ridiculously irrelevant. Responses, observations and questions from the followers were equally ignored by the politicians. There is a failure to leverage the interactive nature of the social media platforms. The communicative dialogues as propounded by the Information Society Theory did not reflect in the online interaction of the two candidates considered.

\section{RECOMMENDATIONS}

Based on our findings, we recommend that media strategists of Nigerian politicians should always make their engagement with the citizens two-way symmetrical. That is, they should develop a strategy to always respond to salient questions and observations the followers of their principals raise on political discussions. Politicians should never downplay the significance of Twitter, Facebook and LinkedIn as they engage citizens on issue-based discussions during political campaigns. In using these media, there should be a convergence where similar issues would be discussed 
simultaneously on the social media platforms. Emphasis should also be placed on generating conversations on real campaign issues. The social media platform should not be seen as a dumping ground to show off attendance at their offline rallies. Future researches on online/social media communication behaviour of Nigerian political candidates should examine post-election social media engagement of the eventual winners to find out whether they stop interacting with their followers on the cyberspace or they continue to engage them with the pre-election campaign promises they rolled out on social media. This, it is believed, would establish more insights into the political behaviour of Nigerian politicians online.

\section{REFERENCES}

Aduloju, A. A. (2016). Youth Networks on Facebook and Twitter during the 2015 General Elections in Nigeria" Journal of African Elections, 15(2), 28-49.

Aichholzer, G., \& Allhutter, D. (2008). Evaluation perspectives and key criteria in eParticipation. Proceedings of the 6th Eastern European eGovernment Days.

Akinlade, A. A. (2015). The Influence of Social Media on the Voting Behaviour of the Youth in South East Nigeria. [An MSc Dissertation in Mass Communication]. University of Nigeria, Nsukka.

An, J., Cha, M, \& Crowcroft, J. (2011) Media Landscape in Twitter: A World of New Conventions and Political Diversity. Conference Proceedings of the Fifth International Conference on Weblogs and Social Media, Barcelona, Catalonia, Spain, July 17-21.

Apuke, O. D. (2017). Public Perception of the Role of Facebook Usage in Political Campaigns in Nigeria. Informing Science: International Journal of Community Development \& Management Studies, Volume 1, 85-102. Asia News Monitor. (2010). South Korea: S. Korea's social networking service users jump 57\% in July. Retrieved from http://search.proquest.com.proxy.lib.umich.edu/docview/1 260391874 ? accountid $=14667$ 
Connected but not Engaged: A Tale of Two Governorship Candidates'

Social Media Mobilization in a Gubernatorial Contest in Oyo State, Southwest Nigeria

Apuke, O. D., \& Apollos, I. N. (2017). Public Perception of the Role of Facebook Usage in Political Campaigns in Nigeria. Informing Science: International Journal of Community Development \& Management Studies, Volume 1, 85-102.

Apuke, O. D., \& Tunca, E. A. (2018). Understanding the Implications of Social Media Usage in the Electoral Processes and Campaigns in Nigeria. Global Media Journal. Volume 16, 1-8.

Ayankoya, K., Calitz, A. P., \& Cullen, M. (2015). A Framework for the use of Social Media for Political Marketing: An Exploratory Study. Retrieved from https:// www.researchgate.net/publication/28244199

Bae, S. Y. (2014). From Encounters to Engagement - Examining Political Engagement in an Age of Social Media. [A PhD dissertation in Communication at the University of Michigan].

Barlett J., Krasodomski-Jones A., Daniel N., Fisher A., \& Jesperson, S. (2015). Social media for election communication and monitoring in Nigeria. [A report prepared for the Department of International Development (DFID)].

Bonneman T. (2013). Public participation: four common misconceptions. Intellitics. com. Retrieved from http://www.intellitics.com/blog/2010/09/25/public-participation-four-common-misconceptions/

Bright, J., Hale, S., Ganesh, B., Bulovsky, A., Margetts, H., \& Howard, P. (2017). Does Campaigning on Social Media Make a Difference? Evidence from candidate use of Twitter during the 2015 and 2017 UK Elections. [A paper presented at the Reuters-OII Seminar].

Calderaro, A. (2018). Social media and politics. In W. Outhwaite \& S. P. Turner (Eds.), The SAGE Handbook of Political Sociology, Two Volumes Set (pp. 781-796). Newbury Park, California: Sage.

Carlisle, J. E. \& Patton, R. C. (2013). Is Social Media Changing How We Understand Political Engagement? An Analysis of Facebook and the 2008 Presidential Election. Political Research Quarterly 66(4), 883-895.

Chinedu-Okek, Chinonye, F., \& Obi, I. (2016). Social media as a political platform in Nigeria: A focus on electorates in South-Eastern Nigeria. Journal of Humanities and Social Science 21(11), 06-22. 
Ching, A. (2018). 4 Vital Reasons to Embrace Infographics in Marketing Campaign. Retrieved from https://piktochart.com/blog/4-vital-reasons-to-embrace-infographics-in-marketing-campaign/

Chu, P. Y., Tseng, H. L., \& Chen, Y. J. (2019). Will Facebook Encourage Citizen Participation?: The Case of Taiwan Legislators' Facebook Strategies. International Journal of Public Administration in the Digital Age. 6(1), 1-14.

David, E., Zhitomirsky-Geffet, M., Koppel, M., \& Uzan, H. (2016). Utilizing Facebook pages of the political parties to automatically predict the political orientation of Facebook users. Online Information Review 40(5), 1-21.

Davies, A., \& Simon, J. (2012). The value and role of citizen engagement in social innovation. A deliverable of the project: The theoretical, empirical and policy foundations for building social innovation in Europe (TEPSIE), European Commission $-7^{\text {th }}$ Framework Programme. Brussels: European Commission, DG Research.

Dike, C. (2018, April 13). Social media and 2019 general election. Nigerian Tribune. Retrieved from https://tribuneonlineng.com/social-media-and-2019-generalelection/

Dunu, I.V. (2018). Social Media And Gubernatorial Elections In Nigeria: A Critical Discourse. IOSR Journal of Humanities And Social Science 23(1), Ver. 3, 6-15.

Effing, R., van Hillegersberg, J., \& Huibers, T. (2011). Social media and political participation: Are Facebook, Twitter and YouTube democratizing our political systems?. In E. Tambouris, A. Macintosh, \& H. de Bruijn (Eds.), Electronic Participation (pp. 25-35). Springer.

Ekman, J., \& Amnå, E. (2012). Political participation and civic engagement: Towards a new typology. Human affairs, 22(3), 283-300.

Enjolras, B. K., Steen-Johnsen, K., \& Wollebaek, D. (2013). Liker - liker ikke: Sosiale medier, samfunnsengasjement og offentlighet (Like - Don't like: social media, community involvement and publicity). Oslo, Norway: Cappelen Damn Akademisk.

European Union (2018). Broadcast Media Readiness and Engagement of Electoral Issues towards the 2019 General Elections in Nigeria. [A Policy Report]. 
Connected but not Engaged: A Tale of Two Governorship Candidates'

Social Media Mobilization in a Gubernatorial Contest in Oyo State, Southwest Nigeria

Ezeibe, C. (2015). Hate Speech and Electoral Violence in Nigeria. [A paper submitted to the Department of Political Science], University of Nigeria, Nsukka.

Haleva-Amir, S. (2011). Present-Absent: Use of Personal Online Tools by Parliament Members In Erez Cohen \& Azi Lev-On (Eds.), Connected: Politics and Technology in Israel (pp. 211-261). Tel Aviv: The Israeli Society of Political Science.

Hemphill, L., \& Roback, A. J. (2014). Tweet acts: how constituents lobby congress via Twitter. Proceedings of the 17th ACM conference on Computer supported cooperative work \& social computing (pp. 1200-1210).

Ifukor, P. (2010). Elections or "Selections"? Blogging and Twittering the Nigerian 2007 General Elections. Bulletin of Science, Technology \& Society 30(6), 398-414.

International Association for Public Participation. (2017). Digital Engagement, Social Media \& Public Participation. [A Working Paper].

International Centre for Investigative Reporting. (2018). Osun Decides 2018: Twitter analysis reveals campaign behaviours of leading candidates. Retrieved from https://www.icirnigeria.org/osundecides2018/

Jibril, K., \& Yakubu, I. (2017). Reactions of Users to the 2015 Presidential Election on Facebook. International Digital Organization for Scientific Research: Journal of Communication and English 2(1), 1-19.

Kamp, M. (2016). Assessing the Impact of Social Media on Political Communication and Civic Engagement in Uganda. [A Report Paper].

Kietzmaan, J. H., Hermkens, K., McCarthy, I. P., \& Silvestre, B. S. (2011). Social Media? Get Serious! Understanding the Functional Building Blocks of Social Media. Business Horizon 54 (3), 241-251.

Lamprianou, I. (2013). Contemporary political participation research: A critical assessment. In Democracy in transition (pp. 21-42). Berlin, Heidelberg: Springer.

Larsson, A. O. (2014). Online, all the time? A quantitative assessment of the permanent campaign on Facebook. New Media \& Society, 18(2), 274-292. https://doi. org/10.1177/1461444814538798

Mead, M. (2018). Citizen Engagement (pp. 153-178). Sage. 
Meskell, D. (2009). Engaging Citizens in Government. Intergovernmental Solutions Newsletter, Fall 2009, 1-44.

Mhlomi, Y., \& Osunkunle, O. (2017). Social media and youth political participation in South Africa's 2014 general election. Communitas, 22, 149-158.

Michael, O. P. (2015). An Evaluation of the Effectiveness of Social Media as Tools for Political Mobilization in Nigeria's 2015 Presidential Election. [A MA Thesis]. Department of Mass Communication, Faculty of Arts, University of Nigeria, Nsukka.

Miller, C. (2016). We are living through a radical shift in the nature of political engagement: the rise of digital politics. London: Demos.

Muntean, A. (2015). The Impact of Social Media Use of Political Participation. [A Master's Thesis in Corporate Communication]. Aarhus University.

Okolo, V. O., Ugonna, I. A., Nebo, G. N., \& Obikeze, C. O. (2017). Effects of the Social Media in the Marketing of Political Candidates in Nigeria. British Journal of Marketing Studies, 5 (6), 15-32.

Okolo, V., Ikechukwu, U., Gerald, N., \& Chinedum, O. (2017). "Effects of the social media in the marketing of political candidates in Nigeria. British Journal of Marketing Studies, 5(6), 15-32.

Okoro, N., \& Nwafor, K. A. (2013). Social media and political participation in Nigeria during the 2011 general elections: The lapses and the lessons. Global Journal of Arts and Humanities and Social Science, 1 (3) 26-46.

Okoro, N., \& Santas, T. (2017). An Appraisal of the Utilisation of Social Media for Political Communication in the 2011 Nigerian Presidential Election. African Research Review, Vol. II (1), 115-135.

Olabamiji, M. O. (2014). Use and Misuse of the New Media for Political Communication in Nigeria’s Fourth Republic. Developing Country Studies, 4(4), 92-102.

Olowojolu, O. (2016). Role of media in 2015 presidential election in Nigeria. International Journal of Politics and Good Governance, 5(7.1). 
Connected but not Engaged: A Tale of Two Governorship Candidates'

Social Media Mobilization in a Gubernatorial Contest in Oyo State, Southwest Nigeria

Orjimi, M. (2018, December 2). 2019: As Candidates Battle On Social Media. Leadership Newspaper.

Quinlan, S., Gummer, T., Roßmann, J., \& Wolf, C. (2017). Show me the money and the party! - variation in Facebook and Twitter adoption by politicians. Information, Communication \& Society, 21(8), 1031-1049.

Satterfield, H. (2016). How Social Media Affects Politics.

Shadrach, I., \& Apuke, O. D. (2020). Investigating the Effectiveness of Social Media Usage for Political Dialogue in Nigeria. Library Philosophy and Practice, January 2020, 1-15.

Spates, S. A., Kaufmann, R., Lin, X., Lachlan, K. A., \& Spence, P. R. (2020). I don't care about who you are, but what you are doing for me? Examining perceptions of helpful comments and identity in user-generated content. Southern Communication Journal, 1-11.

Stieglitz, S., \& Dang-Xuan, L. (2012). Social Media and Political Communication - A Social Media Analytics Framework. Social Network Analysis and Mining 3. https://doi.org/10.1007/s13278-012-0079-3

Theocharis, Y., \& Lowe, W. (2015). Does Facebook increase political participation? Evidence from a field experiment. Information, Communication \& Society, 1-23.

Theocharis, Y., \& Lowe, W. (2016). Does Facebook increase political participation? Evidence from a field experiment. Information, Communication \& Society, 19(10), 1465-1486.

Taiwo, J. (2015). How Social Media Played A Role In Nigeria 2015 Elections. [An Issue Paper].

Tufekci, Z., \& Wilson, C. (2012). Social Media and the Decision to Participate in Political Protest: Observations From Tahrir Square. Journal of Communication. 62(2), 363-379.

Udoka, U. E. (2015). Social Media and Political Effects: A Case Study of the $2015 \mathrm{Ni}$ geria’s Presidential Election. International Journal of Social Science and Humanities Research, Vol. 3, Issue 2, 134-141.

Ugwuanyi, C. J., Olijo, I. I., \& Celestine, G. V. (2019). Social media as tools for po- 
litical views expressed in the visuals Shared among social media users. Library Philosophy and Practice.

Verjee, A., Kwaja, C., \& Onubogu, O. (2018). Nigeria’s 2019 Elections: Change, Continuity, and the Risks to Peace. United States Institute of Peace Special Report. Retrieved from https://www.usip.org/publications/2018/09/nigerias-2019-elections-change-continuity-and-risks-peace\#

Vliegenthart, R., \& Mena Montes, N. (2014). How political and media system characteristics moderate interactions between newspapers and parliaments: Economic crisis attention in Spain and the Netherlands. The International Journal of Press/ Politics, 19(3), 318-339.

Vonderschmitt, K. (2012). The growing use of social media in political campaigns: How to use Facebook, Twitter and YouTube to create an effective social media campaign.

Vraga, K. E., Anderson, A.A., Kotcher, E.J., \& Maibach, E.W. (2015). Issue-Specific Engagement: How Facebook Contributes to Opinion Leadership and Efficacy on Energy and Climate Issues. Journal of Information Technology \& politics, 12(2), 200-218.

Zhang, W., Johnson, T.J. Seltzer, T., \& Bichard, S. L. (2009). The Future Will be Networked. Social Computer Review, 28 (1), 75-92. 